\title{
7,7-Dimethylaporphine and Other Alkaloids from the Bark of Guatteria friesiana
}

Emmanoel V. Costa, ${ }^{* \dagger}{ }^{\dagger}$ Maria Lúcia B. Pinheiro, ${ }^{\dagger}$ Beatriz Helena L. N. S. Maia, ${ }^{\ddagger}$ Francisco A. Marques, ${ }^{\ddagger}$ Ana Lúcia T. G. Ruiz, ${ }^{\S}$ Gabriela M. Marchetti, ${ }^{\S}$ João Ernesto de Carvalho, ${ }^{\S}$ Milena B. P. Soares, ${ }^{\perp, \prod}$ Cinara O. S. Costa, ${ }^{\perp}$ Alexandre F. C. Galvão, ${ }^{\perp}$ Norberto P. Lopes, ${ }^{\#}$ Hector H. F. Koolen, ${ }^{\mathbb{T}}$ Daniel P. Bezerra, ${ }^{\perp}$ and Andersson Barison ${ }^{*}$

${ }^{\dagger}$ Department of Chemistry, Federal University of Amazonas, Manaus 69077-000, Brazil

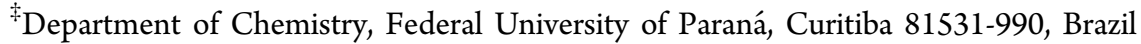

${ }^{\S}$ Chemical, Biological and Agricultural Pluridisciplinary Research Center/CPQBA, University of Campinas, Paulínia 13083-970, Brazil

${ }^{\perp}$ Gonçalo Moniz Research Center, Oswaldo Cruz Foundation/CPqGM-FIOCRUZ, Salvador 40296-710, Brazil

"Biotechnology and Cell Therapy Center, São Rafael Hospital, Salvador 41253-190, Brazil

\#Department of Chemistry and Physics, Faculty of Pharmaceutical Sciences of Ribeirão Preto, University of São Paulo, Ribeirão Preto 14040-903, Brazil

IIDeMpSter Mass Spectrometry Group, Amazonas State University, Manaus 69050-010, Brazil

\section{Supporting Information}

ABSTRACT: Phytochemical investigation of the bark of Guatteria friesiana afforded 12 new aporphines (1-12), along with nine known alkaloids (13-21). The structures of the new alkaloids were determined on the basis of spectroscopic data interpretation. The cytotoxic activity of the isolated compounds against a small panel of tumor cell lines was assessed using the Alamar blue assay.

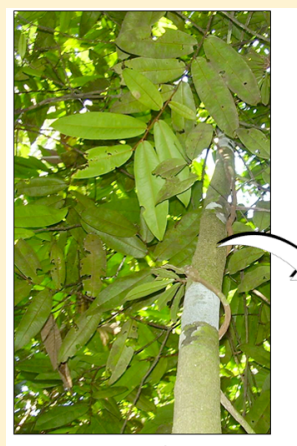

Guatteria friesiana

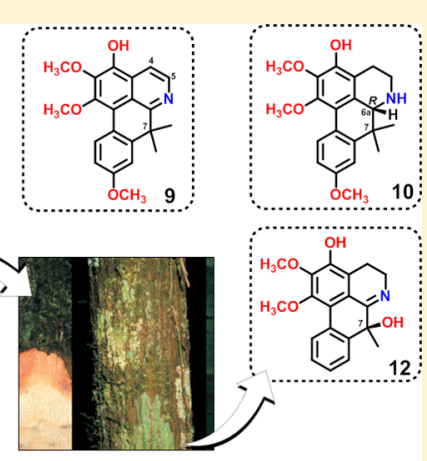

Guatteria Ruiz \& Pav., the largest genus in the plant family Annonaceae, comprises approximately 310 species, all distributed through neotropical regions. ${ }^{1}$ In Brazil, 385 identified species are catalogued, with most occurring in the Amazonian domain. ${ }^{1}$ Some of them are known for their medicinal properties, ${ }^{2}$ as supported by previous investigations revealing bioactive compounds showing potential anticancer, ${ }^{3-6}$ antimicrobial, ${ }^{4,5,7-10}$ antioxidant, ${ }^{7}$ and antiparasitic activities. ${ }^{11,12}$ Guatteria friesiana (W.A. Rodrigues) Erkens \& Maas is known popularly as "envireira" or "envira", and previous phytochemical investigations have described the chemical constituents of its essential oil ${ }^{6,9,13}$ as well as aporphine alkaloids found in its leaves and stem. ${ }^{3,8}$ In a continuing search for bioactive compounds from Amazonian annonaceous plants, 12 new (1-12) and nine previously described (13-21) alkaloids were obtained in a systematic activity-guided investigation of the bark of G. friesiana.

\section{RESULTS AND DISCUSSION}

Compound 1 was obtained as light yellow oil. Its molecular formula of $\mathrm{C}_{20} \mathrm{H}_{19} \mathrm{NO}_{3}$ was determined from its HRESIMS ( $\mathrm{m}$ / $z 322.1443[\mathrm{M}+\mathrm{H}]^{+}$, calcd 322.1438$)$ and ${ }^{13} \mathrm{C}$ NMR data. The IR, UV, and NMR spectra were similar to those reported for demethoxyguadiscine (14). ${ }^{8}$ Analysis of the NMR data (Tables 1 and 2) for 1 and for $14^{8}$ confirmed that these compounds are very similar, except for the presence of a methoxy group at C-3 $\left(\mathrm{s}, \delta_{\mathrm{H}} 4.04\right)$. This was supported by the HMBC correlations of $\mathrm{H}-4$ with $\mathrm{C}-3$ and $\mathrm{CH}_{3} \mathrm{O}-3$ (Tables 1 and 2). Therefore, structure 1 (3-methoxy-demethoxyguadiscine) was established, as shown.

Compound 2 was obtained as a light yellow oil. Its molecular formula was determined to be $\mathrm{C}_{21} \mathrm{H}_{23} \mathrm{NO}_{3}$ from the ${ }^{13} \mathrm{C} \mathrm{NMR}$ (Table 2$)$ and HRESIMS data $\left(m / z 338.1749[\mathrm{M}+\mathrm{H}]^{+}\right.$, calcd 338.1756). Its IR, UV, and NMR spectra (Tables 1 and 2) were similar to those of $\mathbf{1}$. The main differences in the NMR data were related to the absence of the methylenedioxy bridge signal at $\delta_{\mathrm{H}} 6.10(\mathrm{~s})$ present in 1 , which was replaced by two resonances for methoxy groups for 2 at $\delta_{\mathrm{H}} 3.81\left(\mathrm{~s}, \mathrm{CH}_{3} \mathrm{O}-1\right)$

Received: November 19, 2015

Published: June 14, 2016 


\section{Chart 1}

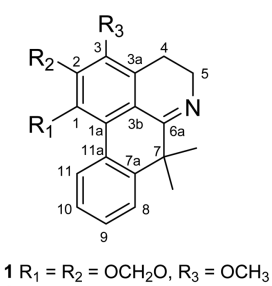

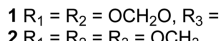

$2 \mathrm{R}_{1}=\mathrm{R}_{2}=\mathrm{R}_{3}=\mathrm{OCH}_{3}$,
$5 \mathrm{R}_{1}=\mathrm{R}_{2}=\mathrm{OCH}_{3} \mathrm{R}_{3}=\mathrm{OH}$ $5 \mathrm{R}_{1}=\mathrm{R}_{2}=\mathrm{OCH}_{3}, \mathrm{R}_{3}=\mathrm{OH}$
$14 \mathrm{R}_{1}=\mathrm{R}_{2}=\mathrm{OCH}_{2} \mathrm{O}, \mathrm{R}_{3}=\mathrm{H}$

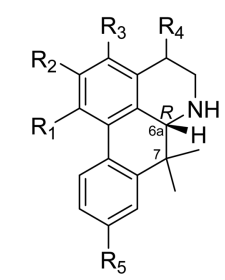

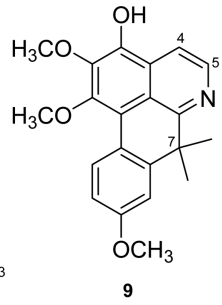

9

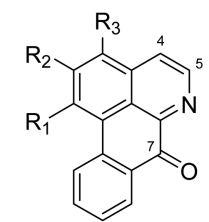

$19 \mathrm{R}_{1}=\mathrm{R}_{2}=\mathrm{OCH}_{3}, \mathrm{R}_{3}=\mathrm{H}$ $20 R_{1}=R_{2}$ $21 R_{1}=R_{2}=O_{3} \mathrm{OCH}_{3}=\mathrm{OH}$<smiles>COc1c(O)c2c3c(c1OC)-c1ccccc1C(C)(C)C3NCC2</smiles>

12

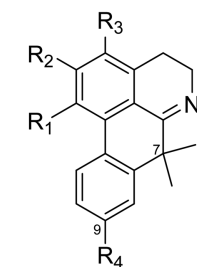

$3 \mathrm{R}_{1}=\mathrm{R}_{2}=\mathrm{R}_{3}=\mathrm{R}_{4}=\mathrm{OCH}_{3}$ $4 \mathrm{R}_{1}=\mathrm{R}_{2}=\mathrm{OCH}_{2} \mathrm{O}, \mathrm{R}_{3}=\mathrm{R}_{4}=\mathrm{OCH}_{3}$ $6 \mathrm{R}_{1}=\mathrm{R}_{2}=\mathrm{R}_{4}=\mathrm{OCH}_{3}, \mathrm{R}_{3}=\mathrm{OH}$ $7 \mathrm{R}_{1}=\mathrm{R}_{2}=\mathrm{R}_{3}=\mathrm{OCH}_{3}, \mathrm{R}_{4}=\mathrm{OH}$ $8 \mathrm{R}_{1}=\mathrm{R}_{2}=\mathrm{OCH}_{3}, \mathrm{R}_{3}=\mathrm{R}_{4}=\mathrm{OH}$ $13 \mathrm{R}_{1}=\mathrm{R}_{2}=\mathrm{OCH}_{2} \mathrm{O}, \mathrm{R}_{3}=\mathrm{OCH}_{3}, \mathrm{R}_{4}=\mathrm{OH}$ $15 \mathrm{R}_{1}=\mathrm{R}_{2}=\mathrm{OCH}_{2} \mathrm{O}, \mathrm{R}_{3}=\mathrm{H}, \mathrm{R}_{4}=\mathrm{OCH} \mathrm{CH}_{3}$
$16 \mathrm{R}_{1}=\mathrm{R}_{2}=\mathrm{OCH}_{2} \mathrm{O}, \mathrm{R}_{3}=\mathrm{H}, \mathrm{R}_{4}=\mathrm{OH}$

$10 \mathrm{R}_{1}=\mathrm{R}_{2}=\mathrm{OCH}_{3} \mathrm{R}_{3}=\mathrm{OH}, \mathrm{R}_{4}=\mathrm{H}, \mathrm{R}_{5}=\mathrm{OCH}_{3}$

$11 R_{1}=R_{2}=R_{3}=O_{C H} C_{4}=H, R_{5}=O H$

$17 \mathrm{R}_{1}=\mathrm{R}_{2}=\mathrm{OCH}_{2} \mathrm{O}, \mathrm{R}_{3}=\mathrm{R}_{4}=\mathrm{R}_{5}=\mathrm{H}$

$18 R_{1}=R_{2}=R_{3}=O_{3}, R_{4}=O H, R_{5}=H$

and $\delta_{\mathrm{H}} 3.91\left(\mathrm{~s}, \mathrm{CH}_{3} \mathrm{O}-2\right)$. On the basis of the spectroscopic data obtained, compound 2 (guatteriscine) was assigned as a new 7,7-dimethylaporphine alkaloid, as shown.

Compound 3 was isolated as a light yellow oil. Its HRESIMS showed a protonated molecular ion peak at $\mathrm{m} / z$ 368.1862 [M+ $\mathrm{H}]^{+}$, indicating a molecular formula of $\mathrm{C}_{22} \mathrm{H}_{25} \mathrm{NO}_{4}$ (calcd 368.1862). A comparative analysis of the NMR data (Tables 1 and 2) for compounds 2 and 3 indicated many similarities between these substances. A difference was the presence of a methoxy group at $\mathrm{C}-9\left(\delta_{\mathrm{H}} 3.86, \mathrm{~s}, \mathrm{CH}_{3} \mathrm{O}-9\right)$ in 3 instead of an aromatic hydrogen, as observed for 2 . The assignment of the substitution at C-9 was obtained from the HMBC correlations between $\mathrm{H}-11$ and $\mathrm{C}-9$, with a further correlation from the methoxy protons at $\mathrm{CH}_{3} \mathrm{O}-9$ with $\mathrm{C}-9$ (Tables 1 and 2). Additionally, a spin system comprising the three protons at $\delta_{\mathrm{H}}$ $7.06(\mathrm{~d}, J=2.7 \mathrm{~Hz}), \delta_{\mathrm{H}} 6.82(\mathrm{dd}, J=8.8$ and $2.7 \mathrm{~Hz})$, and $\mathrm{H}-11$ $\left(\delta_{\mathrm{H}} 8.43, \mathrm{~d}, J=8.8 \mathrm{~Hz}\right)$ was in accordance with the pattern of substitution proposed for 3 (Tables 1 and 2). Therefore, compound 3 (9-methoxyguatteriscine) was established as a new 7,7-dimethylaporphine alkaloid, as shown.

Compound 4 was obtained as a light yellow oil. Its molecular formula of $\mathrm{C}_{21} \mathrm{H}_{21} \mathrm{NO}_{4}$ was determined from the HRESIMS $\left(\mathrm{m} / z\right.$ 352.1549 $[\mathrm{M}+\mathrm{H}]^{+}$, calcd 352.1548$)$ and ${ }^{13} \mathrm{C}$ NMR data. Its IR and UV spectra were closely comparable to those reported for guadiscine (15). ${ }^{14} \mathrm{~A}$ comparative analysis of the NMR data (Tables 1 and 2) for 4 and guadiscine showed a signal for a methoxy group at C-3 $\left(\mathrm{s}, \delta_{\mathrm{H}} 4.01\right)$ in 4 instead of an aromatic proton observed for guadiscine. ${ }^{14}$ This structural proposal was supported by the HMBC correlations of $\mathrm{H}-4$ with C-3 and $\mathrm{CH}_{3} \mathrm{O}-3$ (Tables 1 and 2). Thus, compound 4 (3methoxyguadiscine) was established as a new 7,7-dimethylaporphine alkaloid, as shown.

Compound $\mathbf{5}$ was obtained as a yellow amorphous powder. Its molecular formula was determined to be $\mathrm{C}_{20} \mathrm{H}_{21} \mathrm{NO}_{3}$ from the ${ }^{13} \mathrm{C}$ NMR (Table 2) and HRESIMS data $(\mathrm{m} / z 324.1609$ $[\mathrm{M}+\mathrm{H}]^{+}$, calcd 324.1599). The IR spectrum indicated a hydroxy group $\left(3392 \mathrm{~cm}^{-1}\right)$. A comparative analysis of the NMR data (Tables 1 and 2) for compounds 2 and 5 indicated several similarities between these substances. The main difference apparent was for a C-3-hydroxy substituent in $\mathbf{5}$ that replaced the methoxy group present in 2 . This substitution was confirmed through the HMBC correlations of the H-4 protons with C-3. Therefore, compound 5 (guatterfriesine) was established as a new 7,7-dimethylaporphine alkaloid, as shown.

Compound 6 was obtained as a yellow needle-like solid. Its molecular formula of $\mathrm{C}_{21} \mathrm{H}_{23} \mathrm{NO}_{4}$ was determined from its HRESIMS $\left(m / z 354.1706[\mathrm{M}+\mathrm{H}]^{+}\right.$, calcd 354.1705$)$ and ${ }^{13} \mathrm{C}$ NMR data. A comparison of the IR, UV, and NMR data (Tables 1 and 2) between compounds 5 and $\mathbf{6}$ showed that these two substances are closely comparable, except for the presence of a methoxy group at C-9 for $\mathbf{6}$. Thus, compound 6 (9-methoxyguatterfriesine) was established, as shown.

Compound 7 was isolated as a yellow amorphous powder. Its HRESIMS showed a protonated molecular ion peak at $\mathrm{m} / \mathrm{z}$ 354.1707 $[\mathrm{M}+\mathrm{H}]^{+}$, indicating a molecular formula of $\mathrm{C}_{21} \mathrm{H}_{23} \mathrm{NO}_{4}$ (calcd 354.1705), which was corroborated by the ${ }^{13} \mathrm{C}$ NMR data (Table 2). The IR spectrum indicated the presence of a hydroxy group $\left(3436 \mathrm{~cm}^{-1}\right)$. A comparative analysis of the NMR data (Tables 1 and 2) for compounds 3 and 7 indicated the similar structures of these substances. The main difference was a C-9-hydroxy substituent in 7 replacing the aromatic proton in 3 . This was supported by the HMBC correlation between H-11 and C-9. Therefore, compound 7 (9hydroxyguattescine) was determined as a new regioisomer of 9methoxyguatterfriesine, as shown.

Compound 8 was obtained as a yellow amorphous powder. Its molecular formula of $\mathrm{C}_{20} \mathrm{H}_{21} \mathrm{NO}_{4}$ was determined from its HRESIMS $\left(m / z 340.1544[\mathrm{M}+\mathrm{H}]^{+}\right.$, calcd 340.1549$)$ and ${ }^{13} \mathrm{C}$ NMR data. Its IR, UV, and NMR spectra were similar to those of 5. This was supported by the HMBC correlations of $\mathrm{H}-8, \mathrm{H}-$ 10, and H-11 protons with C-9. Therefore, compound 8 (9hydroxyguatterfriesine) was assigned as a new 7,7-dimethylaporphine alkaloid, as shown.

Compound 9 was obtained as a brown amorphous powder. Its molecular formula was determined to be $\mathrm{C}_{21} \mathrm{H}_{21} \mathrm{NO}_{4}$ from the ${ }^{13} \mathrm{C}$ NMR (Table 2) and HRESIMS data $(\mathrm{m} / z 352.1555$ $[\mathrm{M}+\mathrm{H}]^{+}$, calcd 352.1549). A comparative analysis of the NMR data (Tables 1 and 2) for compounds 6 and 9 indicated many similarities between these substances. The main difference was the presence of aromatic protons at $\delta_{\mathrm{H}} 7.74(\mathrm{~d}, J=5.6 \mathrm{~Hz}, \mathrm{H}-4)$ 


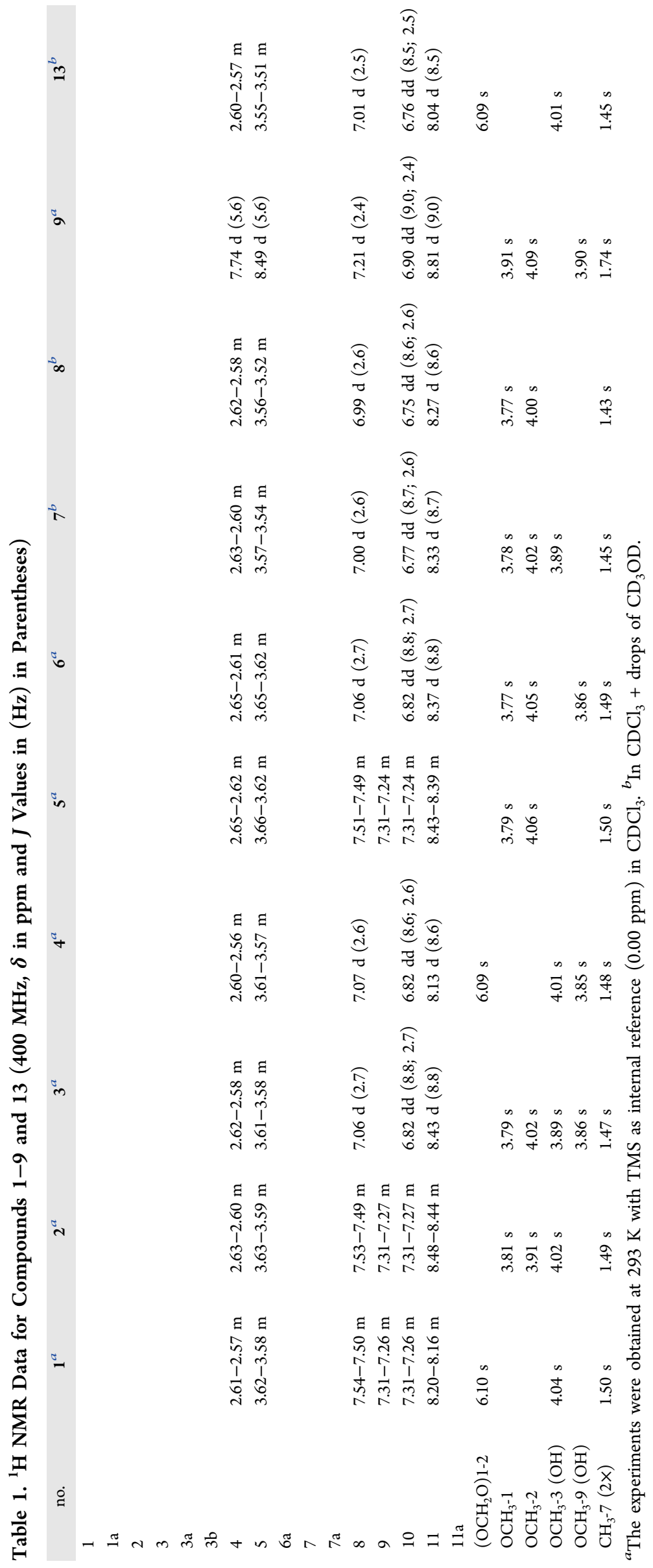




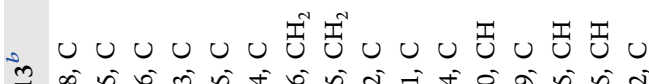

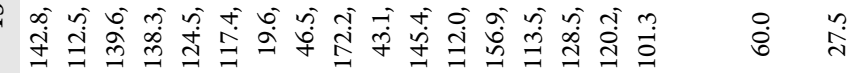

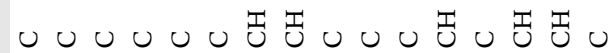

a

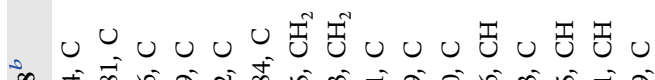

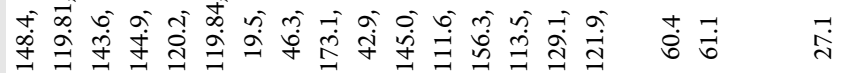

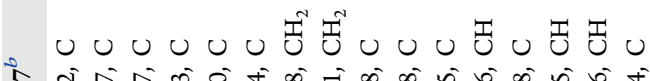

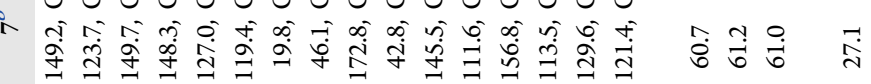

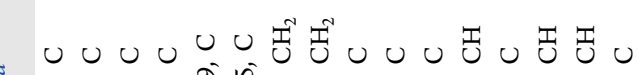

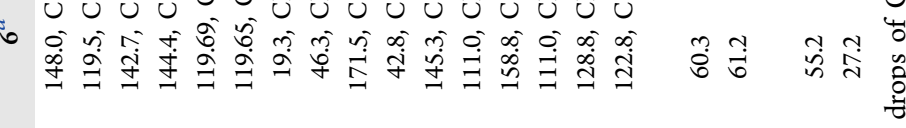

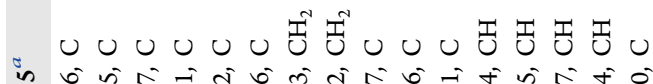

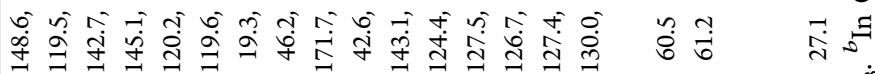

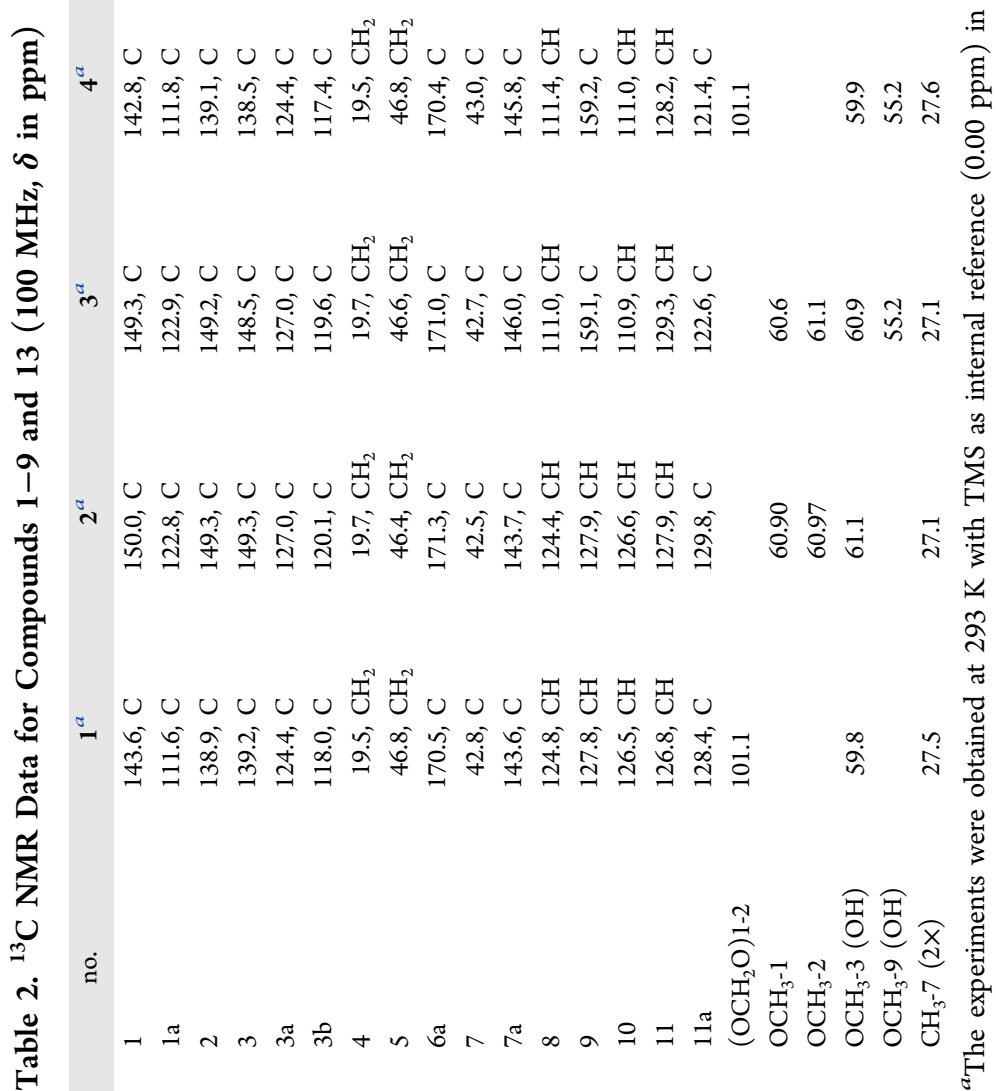


Table 3. ${ }^{1} \mathrm{H}(400 \mathrm{MHz})$ and ${ }^{13} \mathrm{C}$ NMR (100 MHz) Data for Compounds $10-12(\delta$ in ppm and $J$ Values in (Hz) in Parentheses)

\begin{tabular}{|c|c|c|c|c|c|c|}
\hline \multirow[b]{2}{*}{ no. } & \multicolumn{2}{|r|}{$10^{a}$} & \multicolumn{2}{|r|}{$11^{b}$} & \multicolumn{2}{|r|}{$12^{a}$} \\
\hline & $\delta_{\mathrm{C}}$, type & $\delta_{\mathrm{H}}$ mult. $(\mathrm{J}$ in $\mathrm{Hz})$ & $\delta_{\mathrm{C}}$, type & $\delta_{\mathrm{H}}$ mult. $(\mathrm{J}$ in $\mathrm{Hz})$ & $\delta_{\mathrm{C}}$, type & $\delta_{\mathrm{H}}$ mult. $(\mathrm{J}$ in $\mathrm{Hz})$ \\
\hline 1 & 147.6, C & & $148.8, \mathrm{C}$ & & 149.2, C & \\
\hline 1a & 118.4, C & & $122.7, \mathrm{C}$ & & 119.3, C & \\
\hline 2 & 138.5, C & & 145.2, C & & 143.6, C & \\
\hline 3 & 145.6, C & & 149.6, C & & 145.5, C & \\
\hline $3 a$ & 129.7, C & & 124.2, C & & 119.2, C & \\
\hline $3 b$ & 117.4, C & & 129.5, C & & 118.3, C & \\
\hline $4 a x$ & & & & 2.72 dddd $(16.9 ; 11.9 ; 5.6 ; 1.7)$ & & $2.44 \operatorname{td}(16.7 ; 6.1)$ \\
\hline 4eq & 23.4, $\mathrm{CH}_{2}$ & $2.77-2.74 \mathrm{~m}$ & 23.7, $\mathrm{CH}_{2}$ & $2.79 \mathrm{ddt}(16.9 ; 4.2 ; 1.6)$ & 19.5, $\mathrm{CH}_{2}$ & 3.01 ddd $(16.6 ; 5.3 ; 1.0)$ \\
\hline $5 a x$ & & 2.93 ddd $(11.9 ; 10.4 ; 5.7)$ & & $2.88 \operatorname{td}(11.9 ; 4.2)$ & & 3.23 ddd $(16.7 ; 15.0 ; 5.3)$ \\
\hline Seq & 42.6, $\mathrm{CH}_{2}$ & $3.47 \mathrm{dt}(11.9 ; 3.4)$ & 42.7, $\mathrm{CH}_{2}$ & 3.40 ddd $(11.9 ; 5.6 ; 1.6)$ & 45.4, $\mathrm{CH}_{2}$ & 4.11 ddd $(15.0 ; 6.1 ; 1.0)$ \\
\hline $6 a$ & 61.1, $\mathrm{CH}$ & $3.67 \mathrm{~s}$ & $61.5, \mathrm{CH}$ & $3.62 \mathrm{t}(1.6)$ & $170.8, \mathrm{C}$ & \\
\hline 7 & $38.3, \mathrm{C}$ & & $38.1, \mathrm{C}$ & & 72.6, C & \\
\hline $7 \mathrm{a}$ & 146.4, C & & 147.0, C & & $141.8, \mathrm{C}$ & \\
\hline 8 & 109.9, CH & $6.97 \mathrm{~d}(2.7)$ & $110.5, \mathrm{CH}$ & $6.90 \mathrm{~d}(2.6)$ & $124.5, \mathrm{CH}$ & $7.85-7.81 \mathrm{~m}$ \\
\hline 9 & $158.4, \mathrm{C}$ & & 156.2, C & & $127.9, \mathrm{CH}$ & $7.35-7.28 \mathrm{~m}$ \\
\hline 10 & 110.6, CH & $6.81 \mathrm{dd}(8.7 ; 2.7)$ & 113.2, CH & $6.75 \mathrm{dd}(8.6 ; 2.6)$ & $127.5, \mathrm{CH}$ & $7.35-7.28 \mathrm{~m}$ \\
\hline 11 & 129.0, CH & $8.17 \mathrm{~d}(8.7)$ & 129.6, CH & $8.10 \mathrm{~d}(8.6)$ & 126.9, CH & $8.40-8.36 \mathrm{~m}$ \\
\hline $11 \mathrm{a}$ & $123.4, \mathrm{C}$ & & $122.3, \mathrm{C}$ & & $128.4, \mathrm{C}$ & \\
\hline $\mathrm{OCH}_{3}-1$ & 60.1 & $3.67 \mathrm{~s}$ & 60.5 & $3.67 \mathrm{~s}$ & 60.6 & $3.82 \mathrm{~s}$ \\
\hline $\mathrm{OCH}_{3}-2$ & 61.3 & $3.99 \mathrm{~s}$ & 61.1 & $3.96 \mathrm{~s}$ & 61.2 & $4.06 \mathrm{~s}$ \\
\hline $\mathrm{OCH}_{3}-3(\mathrm{OH})$ & & & 60.5 & $3.89 \mathrm{~s}$ & & \\
\hline $\mathrm{OCH}_{3}-9(\mathrm{OH})$ & 55.1 & $3.85 \mathrm{~s}$ & & & & \\
\hline $\mathrm{CH}_{3}-7(\mathrm{OH})$ & 20.8 & $0.88 \mathrm{~s}$ & 20.8 & $0.85 \mathrm{~s}$ & & \\
\hline $\mathrm{CH}_{3}-7$ & 23.3 & $1.49 \mathrm{~s}$ & 23.3 & $1.44 \mathrm{~s}$ & 33.3 & $1.51 \mathrm{~s}$ \\
\hline
\end{tabular}

and $\delta_{\mathrm{H}} 8.49(\mathrm{~d}, J=5.6 \mathrm{~Hz}, \mathrm{H}-5)$, representative of a pyridine ring in 9 . This was supported by the typical coupling constants observed for $\mathrm{H}-4$ and $\mathrm{H}-5$, and by HMBC correlations between $\mathrm{H}-4$ and $\mathrm{H}-5$ with their respective vicinal carbons. On the basis of the spectroscopic data obtained, compound 9 (4,5-dehydro9-methoxyguatterfriesine) was determined as a new 7,7dimethylaporphine alkaloid, as shown.

Compound 10 was obtained as a yellow amorphous powder. Its molecular formula of $\mathrm{C}_{21} \mathrm{H}_{25} \mathrm{NO}_{4}$ was determined from its HRESIMS $\left(m / z 356.1865[\mathrm{M}+\mathrm{H}]^{+}\right.$, calcd 356.1862$)$ and ${ }^{13} \mathrm{C}$ NMR data. A comparative analysis of the NMR data (Tables 1-3) for compounds $\mathbf{6}$ and $\mathbf{1 0}$ confirmed that these two compounds possess similar structures. The main difference observed was the presence of the proton signals at $\delta_{\mathrm{H}} 2.77-$ $2.74(\mathrm{~m}, \mathrm{H}-4), \delta_{\mathrm{H}} 2.93$ (ddd, $J=11.9,10.4$, and $5.7 \mathrm{~Hz}, \mathrm{H}-5_{\mathrm{ax}}$ ), and $\delta_{\mathrm{H}} 3.47\left(\mathrm{dt}, J=11.9\right.$ and $\left.3.4 \mathrm{~Hz}, \mathrm{H}-5_{\mathrm{eq}}\right)$, comprising a tetrahydroisoquinoline system. Additionally, a hydrogen atom at C-6a was observed for $10\left(\delta_{\mathrm{H}} 3.67, \mathrm{~s}, \mathrm{H}-6 \mathrm{a}\right)$ (Table 3). These differences were supported by the absence of characteristic imine resonances $\left(\delta_{\mathrm{C}} 170-173\right)$ in the ${ }^{13} \mathrm{C}$ NMR spectrum of 10. The absolute configuration for this compound was established as $R$ according to the circular dichroism curve (ECD), which showed a negative Cotton effect at $235 \mathrm{~nm}^{15}$ This was also supported by the specific rotation of $10\left([\alpha]^{25}{ }_{D}\right.$ -46.8). ${ }^{8,15}$ Accordingly, compound $10((R)-6,6 a-d i h y d r o-9-$ methoxyguatterfriesine) was assigned as a new 7,7-dimethylaporphine alkaloid, as shown.

Compound 11 was isolated as a yellow amorphous powder. Its molecular formula of $\mathrm{C}_{20} \mathrm{H}_{25} \mathrm{NO}_{4}$ was determined from its HRESIMS $\left(m / z 340.1866[\mathrm{M}+\mathrm{H}]^{+}\right.$, calcd 356.1862$)$ and ${ }^{13} \mathrm{C}$ NMR data. Its IR, UV, and NMR spectra were similar to those of 7. The main difference observed was the presence of methylene protons at C-4 $\left(\delta_{\mathrm{H}} 2.72\right.$, dddd, $J=16.9,11.9,5.6$, and $1.7 \mathrm{~Hz}, \mathrm{H}-4_{\mathrm{ax}}$ and $\delta_{\mathrm{H}} 2.79$, ddt, $J=16.9,4.2$, and $1.6 \mathrm{~Hz}, \mathrm{H}-$ $\left.4_{\text {eq }}\right)$ and at C-5 $\left(\delta_{\mathrm{H}} 2.88, \mathrm{td}, J=11.9\right.$ and $4.2 \mathrm{~Hz}, \mathrm{H}-5_{\mathrm{ax}}$ and $\delta_{\mathrm{H}}$ 3.40 , ddd, $J=11.9,5.6$, and $\left.1.6 \mathrm{~Hz}, \mathrm{H}-5_{\text {eq }}\right)$, constituting a tetrahydroisoquinoline system. The relative configuration of 11 was established by its specific rotation, which appeared to be levorotatory $\left([\alpha]_{\mathrm{D}}^{25}-4.0\right)$, indicating the $\beta$-orientation of the C-6a hydrogen. ${ }^{8,15}$ Thus, compound $11[(R)-4,5,6,6 a-t e t r a h y-$ dromelosmidine] was identified as a known 7,7-dimethylaporphine alkaloid of synthetic origin, ${ }^{14}$ with this being the first report of 11 as a natural compound.

Compound $\mathbf{1 2}$ was isolated as a green amorphous powder. Its molecular formula of $\mathrm{C}_{19} \mathrm{H}_{19} \mathrm{NO}_{4}$ was determined from its HRESIMS $\left(m / z 326.1392[\mathrm{M}+\mathrm{H}]^{+}\right.$, calcd 326.1392$)$ and ${ }^{13} \mathrm{C}$ NMR data. A comparative analysis of NMR data (Tables 1-3) for compounds $\mathbf{5}$ and $\mathbf{1 2}$ confirmed that these two compounds possess similar structures. The main difference was the replacement of a methyl group in 5 by a C-7-hydroxy $\left(\delta_{\mathrm{C}}\right.$ 72.6) substituent in 12. This was supported by the absence of the proton signals in the range $\delta_{\mathrm{H}} 0.88-0.85(\mathrm{~m})$ attributed to one of the methyl groups and by HMBC correlations of the protons at $\delta_{\mathrm{H}} 1.51\left(\mathrm{~s}, \mathrm{CH}_{3}-7\right)$ with $\mathrm{C}-6 \mathrm{a}, \mathrm{C}-7$, and $\mathrm{C}-8$. The relative configuration of $\mathbf{1 2}$ was deduced by comparison of the ${ }^{13} \mathrm{C}$ NMR resonances for the substituents at C-7. Based on the twisted biphenyl-like core of the aporphines, an anisotropic effect is known for C-7 substituents, allowing the assignment of the substituents of this carbon atom. Substituents with an $\alpha$ orientation display unshielded chemical shifts when compared with those with a $\beta$-orientation. ${ }^{3} \mathrm{~A}$ comparison of the ${ }^{13} \mathrm{C}$ NMR resonances of the $\mathrm{CH}_{3}-7$ and C-7 carbons (Table 3) for 12 with those reported for dehydroguatteriopsiscine, ${ }^{3}$ guattouregidine, ${ }^{16}$ and guattouregin ${ }^{16}$ suggested the $\beta$-orientation of the C-7-hydroxy group. Therefore, compound 12 (9-demethox- 
yisoguattouregine) was assigned as a new 7-hydroxy-7methylaporphine alkaloid, as shown.

Additionally, the complete and unambiguous NMR assignments of 9-methoxyguadiscine $(\mathbf{1 3})^{17}$ (Tables 1 and 2), as well as the IR, UV, and NMR data of guadiscine (15) and guadiscidine (16), are reported herein. All other known alkaloids, demethoxyguadiscine (14), ${ }^{8}$ 6,6a-dihydrodemethoxyguadisine $(\mathbf{1 7}){ }^{8}$ guatteriopsiscine $(\mathbf{1 8}){ }^{8}$ lysicamine $(\mathbf{1 9}){ }^{18}$ liriodenine (20), ${ }^{19}$ and isomoschatoline (21), ${ }^{4}$ were assigned by spectroscopic data comparison (NMR and MS) with literature values.

Cytotoxic activities of compounds 1-4, 6-10, 12-15, 17, and 19-21 were evaluated against both tumor and normal cells using an Alamar blue assay (Table S1, Supporting Information). Compounds 5, 11, and $\mathbf{1 6}$ were not tested for their cytotoxic activity due to the small amount of each sample available. Among the compounds tested, liriodenine (20) was the most potent, with $\mathrm{IC}_{50}$ values of $>10,8.3,5.5$, and $5.0 \mu \mathrm{M}$ for the B16-F10 (mouse melanoma), HepG2 (human hepatocellular carcinoma), HL-60 (human promyelocytic leukemia), and K562 (human chronic myelocytic leukemia) tumor cell lines, respectively. Compound 20 exhibited an $\mathrm{IC}_{50}$ value of $34.8 \mu \mathrm{M}$ for human peripheral blood mononuclear cells. Compound $\mathbf{2 0}$ has previously been reported as a cytotoxic agent that binds to DNA and inhibits the action of topoisomerase $\mathrm{II}^{20-24}$

\section{EXPERIMENTAL SECTION}

General Experimental Procedures. Optical rotations were measured on a JASCO P-2000 polarimeter. UV-vis spectra were recorded on an Agilent HP 8453 spectrophotometer, and IR spectra were measured on a Shimadzu IR Prestige-21 spectrometer. ECD spectra were obtained on a JASCO J-720 spectrometer, and measurements were performed in space, by combining 16 scans at a scanning speed of $50 \mathrm{~nm} \mathrm{~min}^{-1}$ from 100 to $500 \mathrm{~nm}$, with a bandwidth of $1 \mathrm{~nm} .{ }^{25} 1 \mathrm{D}$ and $2 \mathrm{D}$ NMR experiments were acquired in $\mathrm{CDCl}_{3}$ or in $\mathrm{CDCl}_{3}+$ drops of $\mathrm{CD}_{3} \mathrm{OD}$ or $\mathrm{CD}_{3} \mathrm{OD}$ at $293 \mathrm{~K}$ on a Bruker AVANCE 400 NMR spectrometer operating at $9.4 \mathrm{~T}\left({ }^{1} \mathrm{H}\right.$ and ${ }^{13} \mathrm{C}$ at 400 and $100 \mathrm{MHz}$, respectively). The NMR spectrometer was equipped with a $5 \mathrm{~mm}$ multinuclear direct detection probe with $z$ gradient. One-bond (HSQC) and long-range (HMBC) ${ }^{1} \mathrm{H}-{ }^{13} \mathrm{C}$ NMR correlation experiments were optimized for the average coupling constants, ${ }^{1} J_{(\mathrm{C}, \mathrm{H})}$ and ${ }^{\mathrm{LR}} J_{(\mathrm{C}, \mathrm{H})}$, of 140 and $8 \mathrm{~Hz}$, respectively. All ${ }^{1} \mathrm{H}$ and ${ }^{13} \mathrm{C}$ NMR chemical shifts $(\delta)$ are presented in ppm relative to the TMS signal at $0.00 \mathrm{ppm}$ as internal reference, and the coupling constants $(J)$ are given in Hz. HRESIMS were obtained on a Bruker UltrOTOF-Q mass spectrometer. Column chromatography was performed on silica gel (Merck, 70-230 mesh). TLC analysis (analytical and preparative) was performed using precoated silica gel 60 F254 ( $0.25 \mathrm{~mm}$, Merck) plates, and spots were visualized by exposure under UV254/365 light, by spraying with $p$-anisaldehyde reagent followed by heating on a plate, or by spraying with Dragendorff's reagent.

Plant Material. The stem bark from a flowering plant of Guatteria friesiana was collected in March 2013 on the experimental farm of the Federal University of Amazonas (UFAM), Manaus, Amazonas State, Brazil, and identified by the plant taxonomist Prof. A. C. Webber at the Department of Biology, UFAM. A voucher (number 9282) was deposited in the Herbarium of UFAM. The Institute Chico Mendes for Biodiversity Conservation provided authorization (\#25637-1) from the Brazilian Ministry of Environment for the plant collection. This work was performed according to the special authorization for access to genetic resources in Brazil \#010240/2013-6, issued by CNPq/ MCTI.

Extraction and Isolation. The dried and powdered bark (1900 g) of $G$. friesiana was extracted with $n$-hexane followed by $\mathrm{MeOH}$, to yield a lipid-free $\mathrm{MeOH}$ extract $(260.6 \mathrm{~g})$. An aliquot of the $\mathrm{MeOH}$ extract $(250 \mathrm{~g})$ was subjected to an acid-base extraction procedure, ${ }^{26}$ giving an alkaloid-containing fraction $(5.07 \mathrm{~g})$. This was subjected to $10 \% \mathrm{NaHCO}_{3}$-treated silica gel column chromatography (CC), eluted with gradient systems of petroleum ether $-\mathrm{CH}_{2} \mathrm{Cl}_{2}$ (100:0 to 10:90), $\mathrm{CH}_{2} \mathrm{Cl}_{2}-\mathrm{EtOAc}$ (100:0 to 10:90), and EtOAc-MeOH (100:0 to 50:50). The eluted fractions were evaluated and pooled according to TLC analysis, resulting in 21 major fractions. Fraction $3(51.0 \mathrm{mg})$, eluted with petroleum ether $-\mathrm{CH}_{2} \mathrm{Cl}_{2}$ (50:50), was purified by preparative TLC, eluted with petroleum ether-acetone $(80: 20,3 \times)$, to give $\mathbf{1}(6.0 \mathrm{mg})$ and $\mathbf{1 4}(14.4 \mathrm{mg})$. Fraction $4(210.2 \mathrm{mg})$, eluted with petroleum ether- $\mathrm{CH}_{2} \mathrm{Cl}_{2}$ (40:60), was purified by silica gel CC (treated with $10 \% \mathrm{NaHCO}_{3}$ solution), using the same methodology as described above for the initial column chromatography of the alkaloid fraction. Subsequent preparative TLC, eluted with petroleum etheracetone $(80: 20,3 \times)$, gave $1(6.7 \mathrm{mg}), 2(4.8 \mathrm{mg}), 3(6.6 \mathrm{mg}), 4(4.3$ $\mathrm{mg}), \mathbf{1 4}(6.7 \mathrm{mg}), \mathbf{1 5}(6.6 \mathrm{mg})$, and $\mathbf{1 7}(18.0 \mathrm{mg})$. Fraction 5 (343.1 $\mathrm{mg}$ ), eluted with petroleum ether- $\mathrm{CH}_{2} \mathrm{Cl}_{2}$ (30:70), was also purified by silica gel $\mathrm{CC}$ (treated with $10 \% \mathrm{NaHCO}_{3}$ solution), using the same methodology as described above, and subsequent preparative TLC, eluted with petroleum ether-acetone $(75: 25,3 \times)$, yielded 6 (23.9 $\mathrm{mg})$ and $18(34.2 \mathrm{mg})$. Fraction $6(683.6 \mathrm{mg})$, eluted with $\mathrm{CH}_{2} \mathrm{Cl}_{2}$ $(100 \%)$, was purified by CC (treated with $10 \% \mathrm{NaHCO}_{3}$ solution) using this same methodology, and subsequent preparative TLC, eluted with petroleum ether-acetone $(70: 30,4 \times)$, yielded $5(8.8 \mathrm{mg}), 6$ $(62.9 \mathrm{mg}), 10(14 \mathrm{mg}), \mathbf{1 2}(6.2 \mathrm{mg})$, and $18(15.3 \mathrm{mg})$. Fraction 8 (329.4 mg), eluted with $\mathrm{CH}_{2} \mathrm{Cl}_{2}-\mathrm{EtOAc}$ (70:30), was also purified by silica gel CC (treated with $10 \% \mathrm{NaHCO}_{3}$ solution) using this methodology described above and then by preparative TLC, eluted with petroleum ether-acetone $(75: 25,3 \times)$, giving $12(10.0 \mathrm{mg})$ and 19 (13.6 mg). Additionally, for fraction 8 , preparative TLC with petroleum ether-acetone $(70: 30,3 \times$, and $75: 25,3 \times)$ resulted in the purification of $7(20 \mathrm{mg}), 11(5.4 \mathrm{mg}), 13(10.5 \mathrm{mg}), 16(3.4 \mathrm{mg})$, and 20 (9.2 mg). Fraction $10(320.1 \mathrm{mg})$, eluted using $\mathrm{CH}_{2} \mathrm{Cl}_{2}-\mathrm{EtOAc}$ (50:50, 40:60, 30:70, and 20:80), was purified by preparative TLC, eluted with $\mathrm{CH}_{2} \mathrm{Cl}_{2}-\mathrm{MeOH}(95: 05,2 \times)$, to give 8 (15.0 mg), 9 (8.3 $\mathrm{mg})$, and $20(69.0 \mathrm{mg})$. Fraction $15(367.6 \mathrm{mg})$, eluted with EtOAc$\mathrm{MeOH}$ (85:15), was purified by silica gel CC (treated with $10 \%$ $\mathrm{NaHCO}_{3}$ solution) using this same methodology as described above, followed by preparative TLC, eluted with $\mathrm{CH}_{2} \mathrm{Cl}_{2}-\mathrm{MeOH}$ (90:10, $2 \times)$, to yield 21 ( $57 \mathrm{mg}$ ).

3-Methoxy-demethoxyguadiscine (1): yellow oil; UV (MeOH) $\lambda_{\max }(\log \varepsilon) 204$ (4.67), 262 (4.50); 296 (3.98), 336 (3.59) nm; IR $\nu_{\max }\left(\right.$ film, $\mathrm{CHCl}_{3}$ ) 2938, 2897, 2844, 1636, 1603, 1571, 1482, 1456, $1418,1386,1337,1293,1206,1144,1094,1057,985,944,831,757$, $664 \mathrm{~cm}^{-1}$; ${ }^{1} \mathrm{H}$ NMR $\left(400 \mathrm{MHz}, \mathrm{CDCl}_{3}\right.$ ) and ${ }^{13} \mathrm{C} \mathrm{NMR} \mathrm{(100} \mathrm{MHz,}$ $\mathrm{CDCl}_{3}$ ) data, see Tables 1 and 2; HRESIMS $m / z 322.1443[\mathrm{M}+\mathrm{H}]^{+}$ (calcd for $\mathrm{C}_{20} \mathrm{H}_{20} \mathrm{NO}_{3}, 322.1443$ ).

Guatteriscine (2): yellow oil; UV (MeOH) $\lambda_{\max }(\log \varepsilon) 204$ (4.40), 232sh (4.14), 252sh (4.41), 260 (4.49), 291 (3.98), 336 (3.54) nm; IR $\nu_{\max }\left(\right.$ film, $\mathrm{CHCl}_{3}$ ) 2960, 2938, 2844, 1629, 1572, 1469, 1414, 1379, $1351,1338,1286,1199,1169,1138,1118,1094,1081,1073,1012$, $965,948,932,836,757,649 \mathrm{~cm}^{-1}$; ${ }^{1} \mathrm{H}$ NMR $\left(400 \mathrm{MHz} \mathrm{CDCl}_{3}\right)$ and ${ }^{13} \mathrm{C}$ NMR $\left(100 \mathrm{MHz}, \mathrm{CDCl}_{3}\right)$ data, see Tables 1 and 2; HRESIMS $\mathrm{m} /$ $z$ 338.1749 $[\mathrm{M}+\mathrm{H}]^{+}$(calcd for $\mathrm{C}_{21} \mathrm{H}_{24} \mathrm{NO}_{3}, 338.1756$ ).

9-Methoxyguatteriscine (3): light yellow oil; UV (MeOH) $\lambda_{\max }$ $(\log \varepsilon) 204$ (4.25), 214sh (4.19), 232sh (4.02), 256sh (4.24), 264 (4.36), 294 (3.91), 344 (3.51) nm; IR $\nu_{\max }$ (film, $\mathrm{CHCl}_{3}$ ) 2937, 2837, $1630,1606,1575,1461,1414,1382,1352,1336,1294,1215,1139$, 1092, 1046, 1013, 966, 948, 823, 756, $595 \mathrm{~cm}^{-1}$; ${ }^{1} \mathrm{H}$ NMR (400 MHz, $\left.\mathrm{CDCl}_{3}\right)$ and ${ }^{13} \mathrm{C}$ NMR $\left(100 \mathrm{MHz}, \mathrm{CDCl}_{3}\right.$ ) data, see Tables 1 and 2; HRESIMS $m / z 368.1862[\mathrm{M}+\mathrm{H}]^{+}$(calcd for $\mathrm{C}_{22} \mathrm{H}_{26} \mathrm{NO}_{4}, 368.1862$ ).

3-Methoxyguadiscine (4): light yellow oil; UV (MeOH) $\lambda_{\max }(\log$ ع) 204 (4.19), 236sh (3.90), 266 (4.23), 272sh (4.20), 292 (3.80), 302 (3.84), 318sh (3.69), $347(3.61) \mathrm{nm}$; IR $\nu_{\max }\left(\right.$ film, $\left.\mathrm{CHCl}_{3}\right)$ 2958, 2938, 2840,1692,1637, 1603,1573, 1507, 1479, 1430,1409, 1384, $1327,1292,1213,1182,1126,1057,987,948,823,756,663,596$ $\mathrm{cm}^{-1}$; ${ }^{1} \mathrm{H}$ NMR $\left(400 \mathrm{MHz}, \mathrm{CDCl}_{3}\right)$ and ${ }^{13} \mathrm{C}$ NMR $(100 \mathrm{MHz}$, $\mathrm{CDCl}_{3}$ ) data, see Tables 1 and 2; HRESIMS $m / z$ 352.1549 $[\mathrm{M}+\mathrm{H}]^{+}$ (calcd for $\mathrm{C}_{21} \mathrm{H}_{22} \mathrm{NO}_{4}, 352.1548$ ). 
Guatterfriesine (5): yellow, amorphous powder; UV $(\mathrm{MeOH}) \lambda_{\max }$ $(\log \varepsilon) 211$ (4.07), 236sh (3.95), 256sh (3.87), 289sh (4.11), 298 (4.17), 342 (3.71), 418 (3.35) nm; IR $\nu_{\max }(\mathrm{KBr}) 3392,2972,2954$, 2930, 2854, 1624, 1576, 1460,1445, 1430, 1413, 1379, 1353, 1304, $1242,1192,1147,1095,1074,1032,982,944,902,842,767 \mathrm{~cm}^{-1} ;{ }^{1} \mathrm{H}$ NMR $\left(400 \mathrm{MHz}, \mathrm{CDCl}_{3}\right)$ and ${ }^{13} \mathrm{C}$ NMR $\left(100 \mathrm{MHz}, \mathrm{CDCl}_{3}\right)$ data, see Tables 1 and 2; HRESIMS $m / z$ 324.1609 $[\mathrm{M}+\mathrm{H}]^{+}$(calcd for $\left.\mathrm{C}_{20} \mathrm{H}_{21} \mathrm{NO}_{3}+\mathrm{H}^{+}, 324.1599\right)$.

9-Methoxyguatterfriesine (6): yellow, needles; UV (MeOH) $\lambda_{\max }$ $(\log \varepsilon) 206$ (4.58), 216 (4.56), 233sh (4.38), 258sh (4.65), 265 (4.74), 294 (4.30), 304sh (4.25), $352(3.78) \mathrm{nm}$; IR $\nu_{\max }(\mathrm{KBr}) 3416,3005$, $2948,2835,1626,1608,1578,1463,1430,1406,1355,1294,1213$, $1143,1092,1076,1045,983,858,829,756,733,594 \mathrm{~cm}^{-1}$; ${ }^{1} \mathrm{H}$ NMR $\left(400 \mathrm{MHz}, \mathrm{CDCl}_{3}\right)$ and ${ }^{13} \mathrm{C} \mathrm{NMR}\left(100 \mathrm{MHz}, \mathrm{CDCl}_{3}\right)$ data, see Tables 1 and 2; HRESIMS $m / z$ 354.1706 $[\mathrm{M}+\mathrm{H}]^{+}$(calcd for $\mathrm{C}_{21} \mathrm{H}_{24} \mathrm{NO}_{4}, 354.1705$ ).

9-Hydroxyguattescine (7): yellow, amorphous powder; UV $(\mathrm{MeOH}) \lambda_{\max }(\log \varepsilon) 214 \mathrm{sh}$ (4.12), 232 (4.16), 289sh (4.06), 301 (4.15), 346 (3.79), 419 (3.45) nm; IR $\nu_{\max }(\mathrm{KBr}) 3436,2988,2966$, 2947, 2931, 2850, 1630,1611, 1576, 1463, 1416, 1404, 1355, 1339, $1297,1245,1213,1195,1141,1095,1040,1012,951,922,864,825$, $811,591 \mathrm{~cm}^{-1}$; ${ }^{1} \mathrm{H}$ NMR $\left(400 \mathrm{MHz}, \mathrm{CDCl}_{3}+\right.$ drops of $\left.\mathrm{CD}_{3} \mathrm{OD}\right)$ and ${ }^{13} \mathrm{C}$ NMR $\left(100 \mathrm{MHz}, \mathrm{CDCl}_{3}+\right.$ drops of $\left.\mathrm{CD}_{3} \mathrm{OD}\right)$ data, see Tables 1 and 2; HRESIMS $m / z 354.1707[\mathrm{M}+\mathrm{H}]^{+}$(calcd for $\mathrm{C}_{20} \mathrm{H}_{22} \mathrm{NO}_{3}$, 354.1705).

9-Hydroxyguatterfriesine (8): yellow, amorphous powder; UV $(\mathrm{MeOH}) \lambda_{\max }(\log \varepsilon) 206$ (4.27), 232sh (4.04), 258sh (4.31), 266 (4.40), 294 (3.96), 304sh (3.91), 354 (3.54) nm; IR $\nu_{\max }$ (KBr) 3539, 3422 , 2967, 2945, 2852, 1630,1611,1579, 1462, 1430,1414, 1355, $1297,1258,1215,1191,1140,1085,1073,1036,978,935,860,823$ 593, $466 \mathrm{~cm}^{-1}$; ${ }^{1} \mathrm{H}$ NMR (400 MHz, $\mathrm{CDCl}_{3}+$ drops of $\left.\mathrm{CD}_{3} \mathrm{OD}\right)$ and ${ }^{13} \mathrm{C}$ NMR (100 MHz, $\mathrm{CDCl}_{3}+$ drops of $\left.\mathrm{CD}_{3} \mathrm{OD}\right)$ data, see Tables 1 and 2; HRESIMS $m / z 340.1544[\mathrm{M}+\mathrm{H}]^{+}$(calcd for $\mathrm{C}_{20} \mathrm{H}_{22} \mathrm{NO}_{4}$, 340.1549).

4,5-Dehydro-9-methoxyguatterfriesine (9): brown, amorphous powder; UV $(\mathrm{MeOH}) \lambda_{\max }(\log \varepsilon) 206$ (4.74), 232 (4.60), 258 (4.59), 318sh (4.09), 333 (4.19), 362 (4.20), 366 (4.22), 370sh (4.21) $\mathrm{nm}$; IR $\nu_{\max }(\mathrm{KBr}) 3439,2955,2936,2848,2834,1610,1595,1570$, $1489,1453,1376,1348,1293,1279,1257,1199,1187,1093,1044$, 983, 956, 917, 884, 834, 795, 729, 688, 605, $554 \mathrm{~cm}^{-1} ;{ }^{1} \mathrm{H}$ NMR (400 $\mathrm{MHz}, \mathrm{CDCl}_{3}$ ) and ${ }^{13} \mathrm{C} \mathrm{NMR}\left(100 \mathrm{MHz}, \mathrm{CDCl}_{3}\right)$ data, see Tables 1 and 2; HRESIMS $m / z$ 352.1555 $[\mathrm{M}+\mathrm{H}]^{+}$(calcd for $\mathrm{C}_{21} \mathrm{H}_{22} \mathrm{NO}_{4}$, 352.1549).

(R)-6,6a-Dihydro-9-methoxyguatterfriesine (10): yellow, amorphous powder; $[\alpha]_{\mathrm{D}}^{25}-46.8$ (c $\left.0.66, \mathrm{CHCl}_{3}\right) ; \mathrm{UV}(\mathrm{MeOH}) \lambda_{\max }$ $(\log \varepsilon) 208$ (4.15), 222sh (4.04), 268sh (3.84), 286 (3.90), 302sh (3.75), $351(2.65) \mathrm{nm}$; ECD $($ c $0.66 \mathrm{~g} / \mathrm{mL}, \mathrm{MeOH}) \lambda_{\max }(\Delta \varepsilon)-22.2$ (235); IR $\nu_{\max }(\mathrm{KBr}) 3433,2934 ; 2836,1608,1460,1430,1410,1375$, $1353,1297,1278,1212,1196,1087,1070,1044,1030,980,817,595$ $\mathrm{cm}^{-1}$; ${ }^{1} \mathrm{H}$ NMR $\left(400 \mathrm{MHz}, \mathrm{CDCl}_{3}\right)$ and ${ }^{13} \mathrm{C}$ NMR (100 $\mathrm{MHz}$, $\mathrm{CDCl}_{3}$ ) data, see Table 3; HRESIMS $m / z 356.1865[\mathrm{M}+\mathrm{H}]^{+}$(calcd for $\mathrm{C}_{21} \mathrm{H}_{26} \mathrm{NO}_{4}, 356.1862$ ).

(R)-4,5,6,6a-Tetrahydromelosmidine (11): yellow, amorphous powder; $[\alpha]_{\mathrm{D}}^{25}-4.0$ (c 0.05, MeOH); UV (MeOH) $\lambda_{\max }(\log \varepsilon)$ 210 (4.59), 222sh (4.52), 234sh (4.30), 284 (4.35), 298sh (4.24) nm; IR $\nu_{\max }(\mathrm{KBr}) 3436,2976,2934,1640,1610,1560,1461,1418,1371$, $1341,1297,1237,1222,1085,1016,962,923,857,659 \mathrm{~cm}^{-1} ;{ }^{1} \mathrm{H}$ NMR $\left(400 \mathrm{MHz}, \mathrm{CDCl}_{3}+\right.$ drops of $\left.\mathrm{CD}_{3} \mathrm{OD}\right)$ and ${ }^{13} \mathrm{C}$ NMR $(100$ $\mathrm{MHz}, \mathrm{CDCl}_{3}+$ drops of $\left.\mathrm{CD}_{3} \mathrm{OD}\right)$ data, see Table 3; HRESIMS $\mathrm{m} / z$ $356.1866[\mathrm{M}+\mathrm{H}]^{+}$(calcd for $\mathrm{C}_{21} \mathrm{H}_{26} \mathrm{NO}_{4}, 356.1862$ ).

9-Demethoxyisoguattouregine (12): green, amorphous powder; $[\alpha]_{\mathrm{D}}^{25}-9.1(c 0.7, \mathrm{MeOH}) \mathrm{UV}(\mathrm{MeOH}) \lambda_{\max }(\log \varepsilon) 204(3.96)$, 222sh (3.78), 236sh (3.71), 256sh (3.93), 2.64 (3.99), 292 (3.50), 344 (3.09) nm; IR $\nu_{\max }(\mathrm{KBr}) 3411,2926,2850,1640,1578,1458,1417$, 1351, 1253, 1217, 1194, 1171, 1138, 1117, 1077, 1034, 983, 953, 921, 848, 760, 664, 638, $570 \mathrm{~cm}^{-1}$; ${ }^{1} \mathrm{H}$ NMR (400 MHz, CDCl $)$ and ${ }^{13} \mathrm{C}$ NMR (100 MHz, $\mathrm{CDCl}_{3}$ ) data, see Table 3; HRESIMS $m / z 326.1392$ $[\mathrm{M}+\mathrm{H}]^{+}$(calcd for $\left.\mathrm{C}_{19} \mathrm{H}_{20} \mathrm{NO}_{4}, 326.1392\right)$.

3-Methoxyguadiscidine (13): yellow, amorphous powder; UV $(\mathrm{MeOH}) \lambda_{\max }(\log \varepsilon) 204$ (4.37), 234sh (4.12), 266 (4.46), 294
(4.02), 302 (4.02), 352 (3.73) nm; IR $\nu_{\max }(\mathrm{KBr}) 3432,2996,2946$, $2854,1637,1603,1508,1457,1423,1387,1332,1300,1253,1209$, 1062, 987, 954, 820, 654, 602, 576, $530 \mathrm{~cm}^{-1}$; ${ }^{1} \mathrm{H}$ NMR $(400 \mathrm{MHz}$, $\mathrm{CDCl}_{3}+$ drops of $\left.\mathrm{CD}_{3} \mathrm{OD}\right)$ and ${ }^{13} \mathrm{C} \mathrm{NMR}\left(100 \mathrm{MHz}, \mathrm{CDCl}_{3}+\right.$ drops of $\mathrm{CD}_{3} \mathrm{OD}$ ) data, see Tables 1 and 2; HRESIMS $m / z$ 338.1391 [M + $\mathrm{H}]^{+}$(calcd for $\mathrm{C}_{20} \mathrm{H}_{20} \mathrm{NO}_{4}, 338.1392$ ).

Guadiscine (15): yellow, amorphous powder; UV (MeOH) $\lambda_{\max }$ $(\log \varepsilon) 204$ (4.08), 230sh (3.91), 264 (4.14), 302 (3.78), 318sh (3.70), 339 (3.58), 352sh (3.54) nm; IR $\nu_{\max }$ (film, $\mathrm{CHCl}_{3}$ ) 2925, 2849, 1635, $1608,1573,1511,1459,1442,1414,1380,1312,1282,1250,1229$, $1215,1186,1075,1049,943,846,815,756,663,603 \mathrm{~cm}^{-1} ;{ }^{1} \mathrm{H}$ NMR $\left(400 \mathrm{MHz}, \mathrm{CDCl}_{3}\right) \delta_{\mathrm{H}} 8.20(1 \mathrm{H}, \mathrm{d} 8.6 \mathrm{~Hz}, \mathrm{H}-11), 7.09(1 \mathrm{H}, \mathrm{d}, 2.6 \mathrm{~Hz}$, $\mathrm{H}-8), 6.84(1 \mathrm{H}, \mathrm{dd}, 8.6$ and $2.6 \mathrm{~Hz}, \mathrm{H}-10), 6.62(1 \mathrm{H}, \mathrm{s}, \mathrm{H}-3), 6.09$ $\left(2 \mathrm{H}, \mathrm{s}, \mathrm{OCH}_{2} \mathrm{O}\right), 3.86\left(3 \mathrm{H}, \mathrm{s}, \mathrm{OCH}_{3}-9\right), 3.64-3.60(2 \mathrm{H}, \mathrm{m}, \mathrm{H}-5)$, $2.59-2.56(2 \mathrm{H}, \mathrm{m}, \mathrm{H}-4), 1.49\left(6 \mathrm{H}, \mathrm{s}, 2 \times \mathrm{CH}_{3}-7\right) ;{ }^{13} \mathrm{C}$ NMR $(100$ $\mathrm{MHz}, \mathrm{CDCl}_{3}$ ) $\delta_{\mathrm{C}} 170.4$ (C-6a), 159.7 (C-9), 149.5 (C-2), 146.6 (C7a), 141.5 (C-1), 133.0 (C-3a), 128.9 (C-11), 121.3 (C-11a), 117.1 (C-3b), 116.7 (C-1a), 111.4 (C-8), 111.0 (C-10), 106.1 (C-3), 100.9 $\left(\mathrm{OCH}_{2} \mathrm{O}\right), 55.2\left(\mathrm{OCH}_{3}-9\right), 47.1(\mathrm{C}-5), 43.1(\mathrm{C}-7), 27.6\left(\mathrm{CH}_{3}-7,2 \times\right)$, $26.4(\mathrm{C}-4)$; ESIMS $m / z 322[\mathrm{M}+\mathrm{H}]^{+}$.

Guadiscidine (16): yellow, amorphous powder; UV $(\mathrm{MeOH}) \lambda_{\max }$ $(\log \varepsilon) 206$ (4.25), 230sh (4.06), 266 (4.30), 302 (3.92), 318sh (3.83), 342 (3.73), 352sh (3.71) nm; IR $\nu_{\max }$ (KBR) 3422, 2960, 2922, 2849, $1636,1599,1513,1460,1420,1399,1383,1336,1286,1249,1226$, 1214, 1073, 1049, 948, 828, 754, 665, $594 \mathrm{~cm}^{-1}$; ${ }^{1} \mathrm{H}$ NMR $(400 \mathrm{MHz}$, $\mathrm{CDCl}_{3}+$ drops of $\left.\mathrm{CD}_{3} \mathrm{OD}\right) \delta_{\mathrm{H}} 8.12(1 \mathrm{H}, \mathrm{d}, 8.5 \mathrm{~Hz}, \mathrm{H}-11), 7.03(1 \mathrm{H}$, d, $2.5 \mathrm{~Hz}, \mathrm{H}-8), 6.78(1 \mathrm{H}, \mathrm{dd}, 8.5$ and $2.5 \mathrm{~Hz}, \mathrm{H}-10), 6.62(1 \mathrm{H}, \mathrm{s}, \mathrm{H}-$ 3), $6.10\left(2 \mathrm{H}, \mathrm{s}, \mathrm{OCH}_{2} \mathrm{O}\right), 3.57-3.54(2 \mathrm{H}, \mathrm{m}, \mathrm{H}-5), 2.61-2.57(2 \mathrm{H}$, m, H-4), 1.46 (6H, s, $\left.2 \mathrm{x} \mathrm{CH}_{3}-7\right) ;{ }^{13} \mathrm{C} \mathrm{NMR} \mathrm{(100} \mathrm{MHz,} \mathrm{CDCl}_{3}+$ drops of $\left.\mathrm{CD}_{3} \mathrm{OD}\right) \delta_{\mathrm{C}} 172.3$ (C-6a), 157.6 (C-9), 149.9 (C-2), 146.2 (C-7a), 141.7 (C-1), 133.0 (C-3a), 128.6 (C-11), 120.0 (C-11a), 117.0 (C-3b), 117.3 (C-1a), 111.7 (C-8), 113.2 (C-10), 105.5 (C-3), 100.8 $\left(\mathrm{OCH}_{2} \mathrm{O}\right), 46.3$ (C-5), 43.1 (C-7), $27.4\left(\mathrm{CH}_{3}-7,2 \times\right), 26.1(\mathrm{C}-4)$; ESIMS $m / z 308[\mathrm{M}+\mathrm{H}]^{+}$.

Cytotoxicity Assay. The B16-F10 (mouse melanoma), HepG2 (human hepatocellular carcinoma), K562 (human chronic myelocytic leukemia), and HL-60 (human promyelocytic leukemia) tumor cell lines were kindly donated by Hospital A.C. Camargo, São Paulo, SP, Brazil. All cell lines were tested for mycoplasma with a mycoplasma stain kit (Sigma-Aldrich) and found to be free from contamination. To obtain normal cells, heparinized blood (from healthy, 20-35-year-old, nonsmoker donors who had not taken any drug at least 15 days prior to sampling) was collected, and peripheral blood mononuclear cells were isolated by a standard protocol using Ficoll (GE Ficoll-Paque Plus) density gradient centrifugation. ConA $(10 \mu \mathrm{g} / \mathrm{mL})$ was added at the beginning of culture, and, after $24 \mathrm{~h}$, cells were treated with the test compound. The Research Ethics Committee of the Oswaldo Cruz Foundation (Salvador, Bahia, Brazil) approved the experimental protocol (number 031019/2013).

Cell viability was quantified by the Alamar blue method, as previously described ${ }^{27}$ with minor modifications. ${ }^{28}$ The positive control was doxorubicin ( $\mathrm{IC}_{50} 2.3 \mu \mathrm{M}$ against B16-F10, $0.2 \mu \mathrm{M}$ against HepG2, $0.7 \mu \mathrm{M}$ against K562, and 0.8 against HL-60 cells).

Statistical Analyses. Data are presented as half maximal inhibitory concentration $\left(\mathrm{IC}_{50}\right)$ values obtained by nonlinear regression. All statistical analyses were performed using the GraphPad program (Intuitive Software for Science, San Diego, CA, USA).

\section{ASSOCIATED CONTENT}

\section{S Supporting Information}

The Supporting Information is available free of charge on the ACS Publications website at DOI: 10.1021/acs.jnatprod.5b01037.

ECD, 1D NMR, 2D NMR, and HRESIMS of compounds 1-13 (PDF) 


\section{AUTHOR INFORMATION}

\section{Corresponding Author}

*Tel (E. V. Costa): +55-92-981388085. Fax: +55-92-3305-

2868. E-mail: emmanoelvc@gmail.com.

\section{Notes}

The authors declare no competing financial interest.

\section{ACKNOWLEDGMENTS}

The authors are grateful to Prof. Dr. A. C. Webber of the Amazonas Federal University (UFAM), Brazil, for the botanical identification, and to Prof. R. F. Swarthout for the help with the translation. We also thank Msc. R. Galaverna from UNICAMP for the ECD measurements and J. C. Tomaz from USP for support with the MS experiments, as well as CAPES, CNPq, FINEP, FAPESB, Fundação Araucária-Paraná, UFAM, and UFPR, for financial support.

\section{REFERENCES}

(1) Lobão, A. Q.; Mello-Silva, R.; Forzza, R. C. Rodriguésia 2012, 63, 1039-1064.

(2) Corrêa, M. P. Dicionário das Plantas úteis do Brasil e das Exóticas Cultivadas; IBDF: Rio de Janeiro, 1984; p 49.

(3) Costa, E. V.; Cruz, P. E. O.; Pinheiro, M. L. B.; Marques, F. A.; Ruiz, A. L. T. G.; Marchetti, G. M.; Carvalho, J. E.; Barison, A.; Maia, B. H. L. N. S. J. Braz. Chem. Soc. 2013, 24, 788-796.

(4) Costa, E. V.; Marques, F. A.; Pinheiro, M. L. B.; Braga, R. M.; Delarmelina, C.; Duarte, M. C. T.; Ruiz, A. L. T. G.; Carvalho, J. E.; Maia, B. H. L. N. S. J. Braz. Chem. Soc. 2011, 22, 1111-1117.

(5) Palazzo, M. C.; Wright, H. L.; Agius, B. R.; Wright, B. S.; Moriarity, D. M.; Haber, W. A.; Setzer, W. N. Rec. Nat. Prod. 2009, 3, 153-160.

(6) Brito, A. C. S.; Oliveira, A. C.; Henriques, R. M.; Cardoso, G. M. B.; Bomfim, D. S.; Carvalho, A. A.; Moraes, M. O.; Pessoa, C.; Pinheiro, M. L. B.; Costa, E. V.; Bezerra, D. P. Planta Med. 2012, 78, 409-414.

(7) Costa, E. V.; Pinheiro, M. L. B.; Barison, A.; Campos, F. R.; Salvador, M. J.; Maia, B. H. L. N. S.; Cabral, E. C.; Eberlin, M. N. J. Nat. Prod. 2010, 73, 1180-1183.

(8) Costa, E. V.; Marques, F. A.; Pinheiro, M. L. B.; Vaz, N. P.; Duarte, M. C. T.; Delarmelina, C.; Braga, R. M.; Maia, B. H. L. N. S. J. Nat. Prod. 2009, 72, 1516-1519.

(9) Costa, E. V.; Teixeira, S. D.; Marques, F. A.; Duarte, M. C. T.; Delarmelina, C.; Pinheiro, M. L. B.; Trigo, J. R.; Maia, B. H. L. N. S. Phytochemistry 2008, 69, 1895-1899.

(10) Zhang, Z.; ElSohly, H. N.; Jacob, M. R.; Pasco, D. S.; Walker, L. A.; Clark, A. M. J. Nat. Prod. 2002, 65, 856-859.

(11) Montenegro, H.; Gutiérrez, M.; Romero, L. I.; Ortega-Barría, E.; Capson, T. L.; Rios, L. C. Planta Med. 2003, 69, 677-679.

(12) Mahiou, V.; Roblot, F.; Fournet, A.; Hocquemiller, R. Phytochemistry 2000, 54, 709-716.

(13) Aciole, S. D. G.; Piccoli, C. F.; Duque, L. J. E.; Costa, E. V.; Navarro-Silva, M. A.; Marques, F. A.; Maia, B. H. L. N. S.; Pinheiro, M. L. B.; Rebelo, M. T. Rev. Colomb. Entomol. 2011, 37, 262-268.

(14) Guinaudeau, H.; Leboeuf, M.; Cavé, A. J. Nat. Prod. 1983, 46, $761-835$.

(15) Ringdahl, B.; Chan, R. P. K.; Craig, J. C.; Cava, M. P.; Shamma, M. J. Nat. Prod. 1981, 44, 80-85.

(16) Leboeuf, M.; Cortes, D.; Hocquemiller, R.; Cavé, A. Planta Med. 1983, 48, 234-245.

(17) Rabelo, D. M.; Pinheiro, M. L. B.; Barison, A.; Salomé, K. S.; Costa, E. V.; Silva, F. M. A.; Chaves, Y. O.; Bastos, I. S. Quim. Nova 2014, 37, 1453-1458.

(18) Harrigan, G. G.; Gunatilaka, A. A. L.; Kingston, D. G. I.; Chan, G. W.; Johnson, R. K. J. Nat. Prod. 1994, 57, 68-73.

(19) Costa, E. V.; Pinheiro, M. L. B.; Souza, A. D. L.; Barison, A.; Campos, F. R.; Valdez, R. H.; Ueda-Nakamura, T.; Dias Filho, B. P.; Nakamura, C. V. Molecules 2011, 16, 9714-9720.
(20) Chen, C. Y.; Chen, S. Y.; Chen, C. H. Process Biochem. 2012, 47, $1460-1468$

(21) Chang, H. C.; Chang, F. R.; Wu, Y. C.; Lai, Y. H. Kaohsiung J. Med. Sci. 2004, 20, 365-371.

(22) Li, L.; Xu, Y.; Wang, B. Oncol. Lett. 2015, 9, 1121-1127.

(23) Woo, S. H.; Reynolds, M. C.; Sun, N. J.; Cassady, J. M.; Snapka, R. M. Biochem. Pharmacol. 1997, 54, 467-473.

(24) Stévigny, C.; Bailly, C.; Quetin-Leclercq, J. Curr. Med. Chem.: Anti-Cancer Agents 2005, 5, 173-182.

(25) Koolen, H. H. F.; Gomes, A. F.; Schwab, N. V.; Eberlin, M. N.; Gozzo, F. C. J. Am. Soc. Mass Spectrom. 2014, 25, 1181-1191.

(26) Costa, E. V.; Pinheiro, M. L. B.; Xavier, C. M.; Silva, J. R. A.; Amaral, A. C. F.; Souza, A. D. L.; Barison, A.; Campos, F. R.; Ferreira, A. G.; Machado, G. M. C.; Leon, L. L. P. J. J. Nat. Prod. 2006, 69, 292-294.

(27) Ahmed, S. A.; Gogal, R. M.; Walsh, J. E. J. Immunol. Methods 1994, 170, 211-224.

(28) Bomfim, L. M.; Menezes, L. R. A.; Rodrigues, A. C. B. C.; Dias, R. B.; Gurgel, C. A. R.; Soares, M. B. P.; Neto, A. F. S.; Nascimento, M. P.; Campos, A. F.; Silva, L. C. R. C.; Costa, E. V.; Bezerra, D. P. Basic Clin. Pharmacol. Toxicol. 2016, 118, 208-213. 